\title{
Correlation Analysis on the Environment Protection Industry Investment with Economic Growth
}

\author{
Jianna Zhao \\ Department of Economics and Management \\ North China Electric Power University, China \\ No.689 Huadian Road, Beishi district, Baoding, 071003, \\ China \\ zhjnzhf@163.com
}

\begin{abstract}
The purpose of the present study was to analyze on the environment protection industry investment with economic growth. This paper describes the current situation that the scale and structure of environmental protection investment and the growth of economic in china during the past 15years and analyses the correlation between them with regression analysis. Although the scale of environmental protection continues to expand, but the growth rate is not stable and there is no stable growth trend. Besides, the growth rate of GDP has declined in recent years. According to the regression results, it is found that the problem that exists in the development, and some suggestions are proposed, including establish a stable and effective investment mechanism, make full use of the stock market to finance and so on, so that promote the sustainable development of China's economy in a better way.
\end{abstract}

Keywords-environmental protection investment; economic growth; correlation analysis

\section{INTRODUCTION}

With the rapid economic development, the environmental problems are getting serious increasingly so the development of environment protection industry has attracted more and more attention from the government. It is rising that the total amount of environmental protection investment in China. In the last century 90s, the amount of investment in environmental protection was only 1307 hundred million. Until the " $12^{\text {th }}$-fiveyear" planning published, the environmental protection investment demand is about 3.4 trillion in China. At the same time, the proportion is increasing that the environmental protection industry investment accounted for the GDP and it is exceeded $1 \%$ for the first time in 1999. In recent years, the upward trend is obvious, in 2014, the investment in environmental protection accounted for $1.5 \%$ of the same period GDP. The increase of investment in environmental protection will also play a certain role in economic growth. Environmental protection investment as a source of capital formation can directly and favorably affect economic growth. Besides, environmental industry can also have an impact on other economic sectors, to promote the development of related industries, and bring economic benefits.

\author{
Di Xin \\ Department of Economics and Management \\ North China Electric Power University, China \\ No.689 Huadian Road, Beishi district, Baoding, 071003, \\ China \\ xindilove@163.com
}

\section{Current Situation}

A. Analysis of scale and structure of environmental protection investment

Since entering in twenty-first Century, China's environmental protection industry development scale has been expanding, and the total investment has been continuously improved.

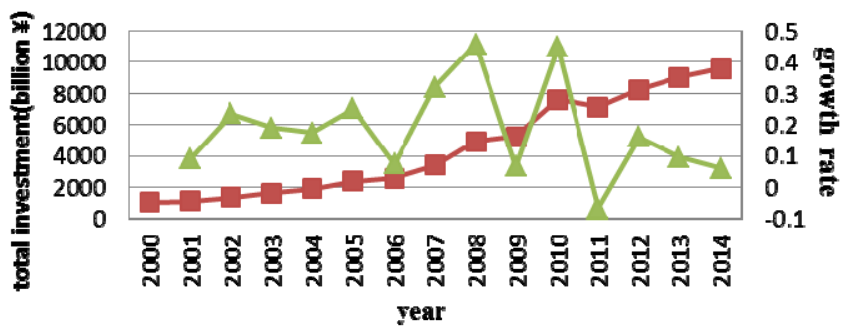

-Environmental total investment(billion $¥$ )

Growth rate of investment in environmental protection

Fig. 1. The environmental total investment and growth rate

It is can be seen from the figure that China's environmental protection industry investment continued to grow showing a rising trend overall and ensures the development of environmental protection industry in the capital and development momentum. However, from the figure, environmental protection industry investment growth rate is volatiles. The growth rate reached about $45 \%$ in 2008 and 2010 , but the growth rate is $-6.5 \%$ in the 2011 , which reflects the lack of stability of investment in China's environmental protection industry and without an effective stable investment mechanism, and also reflects from the side that China's environmental protection industry has not been fully valued.

On the other hand, from the perspective of investment structure and direction of environmental protection industry, our country's environmental protection investment mainly includes three aspects, at present. ${ }^{[1]}$ It is can be seen from the table I, the rate of urban environmental infrastructure construction investment is the most, and the average is about $57 \%$ in recent 15 years. The rate of construction project "three concurrences" investment takes the second place, and the 
average is about $30 \%$. The rate of industrial pollution control investment is the least, and the average is about $13 \%$.

TABLE I. THE PROPORTION

\begin{tabular}{lccc}
\hline year & $\begin{array}{c}\text { infrastructure } \\
\text { construction }\end{array}$ & $\begin{array}{c}\text { three } \\
\text { concurrences }\end{array}$ & $\begin{array}{c}\text { industrial pollution } \\
\text { control }\end{array}$ \\
\hline 2000 & 0.508 & 0.256 & 0.231 \\
2001 & 0.538 & 0.304 & 0.158 \\
2002 & 0.577 & 0.285 & 0.138 \\
2003 & 0.659 & 0.205 & 0.136 \\
2004 & 0.598 & 0.241 & 0.161 \\
2005 & 0.540 & 0.268 & 0.192 \\
2006 & 0.512 & 0.299 & 0.189 \\
2007 & 0.433 & 0.404 & 0.163 \\
2008 & 0.455 & 0.435 & 0.110 \\
2009 & 0.617 & 0.299 & 0.084 \\
2010 & 0.681 & 0.267 & 0.052 \\
2011 & 0.641 & 0.297 & 0.062 \\
2012 & 0.613 & 0.326 & 0.061 \\
2013 & 0.578 & 0.379 & 0.094 \\
2014 & 0.571 & 0.320 & 0.104 \\
\hline
\end{tabular}

B. China's economic development situation

Since the reform and opening up for 30 years, China's economic level has been rapidly improved and the people's living standard has also got better. While, the pattern of economic development in our country is basically extensive economy. High consumption, high cost, and low economic efficiency, so there are more serious damage to the environment. In order to achieve the sustainable development of the economy in a better way and the harmonious development of economy and environment, our country should continue to develop the intensive economic growth mode instead of extensive economy, and improve the utilization of factors of production.

In the paper, GDP reflects the situation of our country economic develops. It can be seen from the figure 2.2 that in the past 15 years the GDP has been greatly improved. The GDP is only 10 trillion in 2000 , but it has broken 60 trillion until 2014. It is increased by 5 times in the $15 y$ ears reflecting that great achievements have been made in the economic development of our country. However, from the increasing rate, the growth rate of China's economy has a certain fluctuation, without a steady growth trend. Especially, in the recent 5 years, it is zero growth or even negative growth. The reason may be that our country is trying to change from the previous economic increasing model to the intensive economic development country so that we can further to achieve the sustainable development of the economy in a better way.

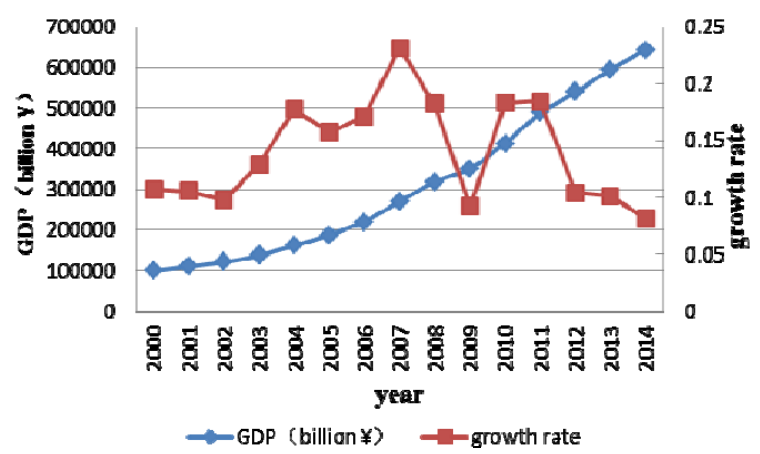

Fig. 2. GDP total amount and growth rate trend char

\section{The CORRELATION ANALYSIS}

\section{A. correlation analysis}

This paper selects three parameters of GDP, fiscal revenue and total social fixed assets investment and to do correlation analysis using $\mathrm{R}$ language.

TABLE II. THE RELATIONSHIP

\begin{tabular}{ccccc}
\hline & GDP & $\begin{array}{c}\text { environmental } \\
\text { investment }\end{array}$ & $\begin{array}{c}\text { fiscal } \\
\text { revenue }\end{array}$ & $\begin{array}{c}\text { fixed } \\
\text { investment }\end{array}$ \\
\hline $\begin{array}{c}\text { GDP } \\
\text { environmental }\end{array}$ & 1.00 & & & \\
investment & 0.987 & 1.00 & & \\
fiscal revenue & 0.999 & 0.984 & 1.00 & \\
fixed investment & 0.992 & 0.971 & 0.993 & 1.00 \\
\hline
\end{tabular}

Analysis results show that environmental protection investment and GDP, fiscal revenue, fixed assets investment has a significant correlation in China. ${ }^{[1]}$

\section{B. regression analysis}

Analysis of the above data, it can be seen that the annual environmental protection investment and GDP is roughly linear relationship. ${ }^{[3]}$ The GDP as independent variables $Y$, the environmental investment as a dependent variable $X$, make the regression analysis, get the following result:

TABLE III. VARIANCE ANLYSIS

\begin{tabular}{cccccc}
\hline & df & SS & MS & F & Significance F \\
\hline $\begin{array}{c}\text { regression } \\
\text { analysis }\end{array}$ & 1 & 0.962543 & 0.984372 & 16.09823 & $1.01 \mathrm{E}-08$ \\
$\begin{array}{c}\text { residual error } \\
\text { total }\end{array}$ & 13 & 1.028942 & 0.079821 & - & 0.000809 \\
\hline
\end{tabular}


TABLE IV. SIMPLE REGRESSION RESULTS

\begin{tabular}{ccccc}
\hline & Coefficients & $\begin{array}{c}\text { Standard } \\
\text { error }\end{array}$ & t Stat & P-value \\
\hline Intercept & 3.120983 & 0.267821 & 11.89201 & $1.01 \mathrm{E}-08$ \\
XVariable1 & 0.487123 & 0.116089 & 4.02103 & 0.000809 \\
\hline
\end{tabular}

According to the regression result, the linear regression equation can be got:

$$
\begin{gathered}
\mathrm{Y}=3.120983+0.487123 \mathrm{X} \\
(0.267821)(0.116089) \\
\mathrm{T} \quad 11.89201 \quad 4.02103 \\
\mathrm{r}^{2}=0.491204 \quad \mathrm{~F}=16.09823
\end{gathered}
$$

The estimated parameters $b=0.487123$, shows that the environment protection increases one unit can lead to the 0.487123 units GDP increasing.

Make significance test of linear regression equation. Firstly, integral test of equation (F-test). In the integral test of equation, $\mathrm{F}=16.09823$, the corresponding probability $\mathrm{P}$ value is 0.000809 . It is far less significant level 0.05 , so the equation is significant. Secondly, test of the estimation of regression coefficients (Ttest). Test statistic $\mathrm{t}=4.02103$, the corresponding probability $\mathrm{P}$ value is $1.01 \mathrm{E}-08$, it is far less significant level 0.05 , so the linear relationship of $\mathrm{X}$ coefficient was significant.

\section{CONCLUSION AND SUGGeSTION}

\section{A. Conclusions in the paper}

According to the current situation of the investment amount of environmental protection, it is can be concluded that the scale of China's environmental protection industry has been expanding but there are still many problems. Firstly, although investment in environmental protection industry is increasing, the growth rate is bigger ups and downs without a kind steady growth trend. It can be concluded that growth rate dropped sharply, and negative growth appeared during 2009 and 2011 and the growth rate has declined after 2009, from the 'environmental protection investment and growth rate trend chart in 2000-2014'. Secondly, investment in environmental protection accounted for a lower proportion of GDP. The various research shows that the proportion of environmental protection investment in GDP during 3\%-5\%, it can significantly improve the quality of the environment. [6] However, China's investment in environmental protection accounted for the proportion of GDP is only $1.2 \%$, far from enough to improve the quality of the environment. What's more, due to the positive externalities of environmental protection industry, its economic benefit is less than the total social income. As a result, it is difficult to finance, and the investment is insufficient.

From the perspective of the impact of environmental protection investment on economic growth, environmental protection investment and gross domestic product are positive correlation. Table II "China's Environmental Investment and Economic Parameters of the Correlation" shows that China's environmental protection investment and GDP, fiscal revenue and investment in fixed assets has a significant correlation. China is in the stage of economic development, which is mainly based on industrialization, and the increase of GDP will inevitably lead to environmental pollution. Therefore, it is generally believed that environmental protection and economic development are mutually contradictory. But in fact, the increase in the amount of investment in environmental protection is of great benefit to the development of the society and economy. Increasing investment in environmental protection can drive the development of related industries and provide new employment opportunities for our country's labor, at the same time, promoting economic development and improving the level of economic efficiency. ${ }^{[4]}$

In the China's investment of environmental protection, city environmental infrastructure construction investment accounted for more than half, but the average of industrial pollution source investment is less than $15 \%$ or even decline and behind the whole investment in environmental protection. Nevertheless, industrial pollution is the main source of environmental pollution in China. Attaching too much importance to the investment in the infrastructure construction can not only lead to the appearance of the rapid increase in environmental protection investment, but also seriously affect the governance of industrial pollution, which is not conducive to the improvement of the environmental situation. As a result, it is very necessary to perfect the investment structure so as to improve our environment and promote the development of environmental protection industry.

\section{B. Related suggestions}

First of all, increasing investment to ensure the attention. It is significant to promote the development of environmental protection industry that increase investment to ensure that the full attention of the environmental protection industry and establish a stable and effective investment mechanism. Capital is a strong driving force for the development of the industry and the sufficient capital is the vital factor to accelerate the development of the industry. Therefore, China should further accelerate the improvement of environmental protection investment soft environment; improve the human environment, the administrative environment and market environment, etc. In order to promote economic growth, our country should adjust the investment structure of environmental protection, guide the regional distribution of environmental protection investment, and implement the environmental protection investment diversification. With the rapid growth of China's economy, the gross domestic product is increasing and investment in environmental protection industry also will increase year by year. Then, between environmental protection investment and economic growth will form a virtuous circle. ${ }^{[2]}$

Secondly, make full use of the security market. Now environmental problems are becoming serious increasingly. The people pay much more and more attention to the environment, so "green product" "green services" are getting the people the favor gradually. The environment protection product market has the development potential, and the environmental protection industry is our country's sunrise industry. ${ }^{[5]}$ In addition, a large amount of money is gradually flowing into the stock market at present. As a result, for the 
environmental protection industry, it is a vital way to make full use of the stock market for financing. For the large scale and the strength of the enterprise can be financed through the stock market, and at present, there are a number of listed environmental protection companies in China. For small and medium enterprises with high technology content can be considered to be listed on the GEM (growth enterprise market) to raise the sufficient funds for the development. In short, making full use of the stock market can promote the rapid development of environmental protection industry.

Thirdly, improve the status of environmental protection industry gradually. In people's traditional idea, paying more attention to environmental protection will inevitably affect the development of economy and lead to economic stagnation or even recession. But in fact, energy saving and environmental protection industry will greatly promote the development of economy. The industry has been identified as a strategic emerging industries by the State Council in 2010, showing the development direction for the energy saving and environmental protection industry. However, only to establish the dominant position of the environmental protection industry in the economic development, can we really promote its rapid development and play its positive role in improving the level of economic efficiency. At this stage, China's investment in environmental protection is increasing, and the value of output is over one trillion. It has initial condition to be transformed into the dominant industry conditions. Therefore, our country should change the guiding ideology for the of environmental protection industry to provide the inner motive force for its development.

\section{REFERENCES}

[1] Wang Huizhi. Analysis of environmental protection investment and its relationship with economic development in Tianjin. [J].(2013).

[2] Zhang Xiaohua. Analysis on the role of environmental protection industry to the sustainable development of China's economy. [D].(2012).

[3] Lei Sheping, He Yinyin. Regression analysis of environmental protection investment and economic growth in China. [J].(2010).

[4] Shao Lili. The regression analysis of environmental protection investment and economic growth -- a case study of Shanxi Province. [J].(2010).

[5] Gao guangkuo, Chen yu. An empirical test of the effect of environmental protection industry on national economic growth. [J].(2008).

[6] Shao Haiqing. Gray correlation analysis between environmental protection investment and national economic growth. [J]. 